\title{
Eco-driving: knowledge and behavior of polish drivers
}

\author{
Piotr Oskar Czechowski ${ }^{1, ~}{ }^{*}$, Aneta Oniszczuk-Jastrząbek ${ }^{2}$, and Tomasz Czuba ${ }^{2}$ \\ ${ }^{1}$ Gdynia Maritime University, Faculty of Entrepreneurship and Quality Science, 81/87 Morska St., \\ 81-225 Gdynia, Poland \\ ${ }^{2}$ University of Gdańsk, Faculty of Economics, 119/121 Armii Krajowej St., 81-824 Sopot, Poland
}

\begin{abstract}
In Poland, similarly as in the entire Europe, the quality of air is shaped primarily by communal-living sources and road transport. Due to the steadily increasing share of city residents in the general population, the issue of providing clean air will become a more significant problem for human health over the years, and therefore a stronger incentive to intensify the research. Hence, the key challenge faced by a modern society is to limit the emissions of harmful substances in order to minimize the impact exerted by transport on air pollution and health. Increasingly stringent emission standards are imposed on car manufacturers while on the other hand, the problem of drivers is being ignored - namely their awareness of possibilities to reduce the emissions and the ways in which they can help protecting also their own health and life by applying the rules related to the concept of ecodriving in practice. The aim of this paper is to present differences in perception of eco-driving principles in two random and nation-wide surveys: one carried out in 2015 and the other in 2017. Initial conclusions show a major increase $(49.4 \%$ to $53.2 \%)$ of eco-driving awareness among respondents in 2017 when compared to 2015.
\end{abstract}

\section{Introduction}

Environmental protection is one of the major challenges faced by a man at the beginning of the 21 st century. One of the pollution sources is transport, including road transport. Its harmful impact on the environment is rooted in the fact that natural resources are limited, while the pressure on their use continues to increase. Therefore, despite development of environmental policy, the degradation carries on, among others because of all environmental burdens which result from transport actions, especially harmful emissions of substances and energy (e.g. vibrations and noise). It happens because the ecological balance is being undermined and the environmental components are being depleted. Unfortunately, it turns out that transport is one of the economic sectors, which exerts the greatest harmful impact on the environment [1].

The article is based on an analysis of primary research which covers interviews with Polish drivers, which have provided grounds for authors' reflections and development of models. The research was conducted twice, in 2015 and 2017. Its main objective was to

\footnotetext{
${ }^{*}$ Corresponding author: p.o.czechowski@wpit.am.gdynia.pl
} 
determine the level of awareness and behaviors in the field of eco-driving. The objective of improving the performance of eco-driving requires its components to be identified. The research results allowed to determine the level of awareness in relation to the eco-driving as well as those actions or demographic features which impact responsible behaviors of Polish drivers to the greatest extent, including identification of factors that contribute to a drop in fuel consumption in a city. The article is a continuation of the previously published own research [2] analyzing the level of drivers' knowledge and their behaviors which influence environmental protection. The article depicts, among other things, a relationship between knowledge and behavior as two elements of shaping the attitudes.

\section{Review of the literature}

Development of the world economy, technical progress and irrational exploitation of natural resources led to an increase in negative results of economic activity, which cause that more and more attention is paid to, e.g. environmental pollution or deterioration in a standard of living of the population. Hence, in recent years, the concept of sustainable development has been enjoying a period of greater interest, accompanied by changes in attitudes and expectations of all market participants. Therefore, the sustainable development model assumes that there is a balance between three equal components: economic, ecological and social, which influence and interact with each other. One of the elements necessary to achieve this balance is the action related to improvement in the natural environment condition $[3,4]$. In addition to various approaches to sustainable transport, it is understood as environmentally balanced mobility, which included all changes in behaviors and unconventional approaches in all economic sectors $[5,6,7]$.

Hence, the unsustainable transport causes negative effects in a form of extensive environmental pollution and absorption of enormous amounts of energy, and the increase in investment outlays in this area fails to improve the quality of provided services. When it comes to transport, those negative effects are considered to be the costs generated in the transport process, which the transport user does not cover at all or covers in full $[8,9]$. It should be also mentioned here that the negative external effects that are associated with external costs are that part of social costs which are not transferred to the user by the market. The internal costs of road transport are composed of: costs of accidents, noise and vibrations emissions, air pollution, water and soil contamination, local/regional/global pollution, congestion, the demand for ground, solid contaminants (wrecks, tires, rubble) [10].

The notion of eco-driving appeared in the second half of 1990s. The eco-driving's assumptions were developed for the first time in Switzerland and Finland. As claimed by authors of this driving style, practical application of some rules (principles) by the drivers should lead to the lowest fuel consumption, and at the same time impact the environmental pollution to the lowest extent. This is why, the popularity of the rule of this driving style among drivers is on a constant increase. Eco-driving is basically a smooth and controlled method of driving a car. The following essential driving tips are offered: plan journeys ahead, anticipate traffic flow, move into the highest possible gear while keeping a constant speed, brake gently by gearing down, turn off the engine when stopped for longer than a minute, avoid engine pre-heating (including in winter), maintain correct tyre pressure, limit air conditioning usage to a reasonable minimum [11]. The relations between individual items on the list are widely discussed by Andoa, Nishihori [12], Andrieu, Saint Pierre [13]. To achieve its aim, the article examines driving awareness and behaviour. Research by other authors shows that eco-driving reduces average fuel consumption by $10 \%$ per kilometre. Also, this manner of driving reduces $\mathrm{CO} 2$ emissions by $6-10 \%$ [14] and fuel consumption in buses by $2 \%$ in the 12 months following training [15] 4.35\% in the two-month follow-up period [16]. The mean change in fuel consumption for all drivers in the study after their eco-driving 
course was a reduction of $5.8 \%$, but with large differences between individuals [17]. As a result of research by Merkisz, Andrzejewski and Pielecha, the lowest emission of all the analyzed harmful substances, i.e. $\mathrm{CO}$. $\mathrm{CO} 2, \mathrm{HC}$ and $\mathrm{NOx}$, from the exhaust system of the tested vehicle, was recorded for eco-driving, while the highest was registered in the case of an aggressive driving style [18]. Furthermore, the authors, despite determining the impact of the employed driving style exerted on the emission of harmful substances through exhaust fumes generated by the tested commercial vehicle, also identified its influence on the volume of consumed fuel. The differences when compared to normal driving are: -0.20 and 0.45 $\mathrm{dm} 3 / 100 \mathrm{~km}$ This leads to reduction in fuel consumption by $2.6 \%$ (eco-driving) and an increase in the same by $6.1 \%$ (aggressive driving) [18]. Hence, less aggressive driving, maintaining the right engine speed, proper air pressure in tires, breaking with the engine or turning the engine off when a car stops for a longer time result in reduction of fuel consumption and thus to lower emission of pollutants and noise. The research carried out by Tokarczyk suggests that even though the pro-ecological behaviors are possible to attain without detailed information, this is the low level of knowledge what is the most frequent cause of lack of such behaviors. The analysis of relations between the level of knowledge and behaviors of drivers and some selected socio-demographic data leads to a conclusion that the knowledge level depends on the driver's gender, education and their place of residence (a higher level was recorded in case of men with higher education, living in big cities) and that ecological behaviors seem to depend on education, age and experience in driving a car [19].

\section{Methodology}

The nationwide study (using the direct interview method (PAPI)) examined how the drivers/passenger vehicles owners employ the rules of eco-driving and how this affects their health. The research was carried out in the between 21th July 2017 and 11th August 2017 on a random sample of 1000 drivers/passenger vehicles owners throughout the country. The attitude to eco-driving was one of the elements of this study that focused on the behaviors and preferences of drivers within the scope of patterns of petrol stations use.

The primary research problem is to answer the questions, where both the dependent and independent variables are expressed in weak scales: nominal and ordinal. It is thus impossible to adopt a classical regression model.

Log-linear models can be used alternatively in such circumstances, in particular their specific case: logistic regression model. It assumes that the dependent variable is a dummy variable, while the independent variables may be expressed in any given measurement scale.

An example explaining the results of the model estimations will be the model of factors which shape the eco-driving awareness (whether the respondent have heard of eco-driving or not) (Table 3.).

The knowledge of eco-driving is a dummy variable - meaning a dependent variable where the lack of knowledge is coded as " 0 " and its presence as " 1 ". The independent variables describing knowledge of eco-driving are expressed in various measurement scales: "age" in an ordinal scale, "gender" in a nominal scale.

If we want to answer the question of which researched variables are the factors which significantly condition the knowledge of eco-driving, we need to say that the most appropriate quantitative methods from those available are the multiple regression models. In the case of evaluating this type of the casual connection, as regards various measurement scales of the research variables, we cannot employ the standard path, namely the multidimensional regression. It was assumed that the logistic regression model will allow for identification of some significant factors what in this case is actually brought down to seeking for a probability connection regarding occurrence of a given variant (had/did not have 
contact) - similar to the regression function - with a group of independent variables such as answers given by the respondents and other factors, e.g. gender.

\subsection{Logistic regression model}

The advantage of logistic regression is the fact that analysis and interpretation of results are similar to those of the classical regression models [20, 21, 22, 23].

In other words, the logistic regression is a certain mathematical model which can be employed to describe several variables $x_{1}, x_{2}, \ldots x_{k}$ (expressed in any measurement scale) for the dummy variable $y$.

The logistic regression model is based on a logistic function in a form of (Fig. 1.):

$$
f(z)=\frac{e^{z}}{1+e^{z}}=\frac{1}{1+e^{-z}}
$$

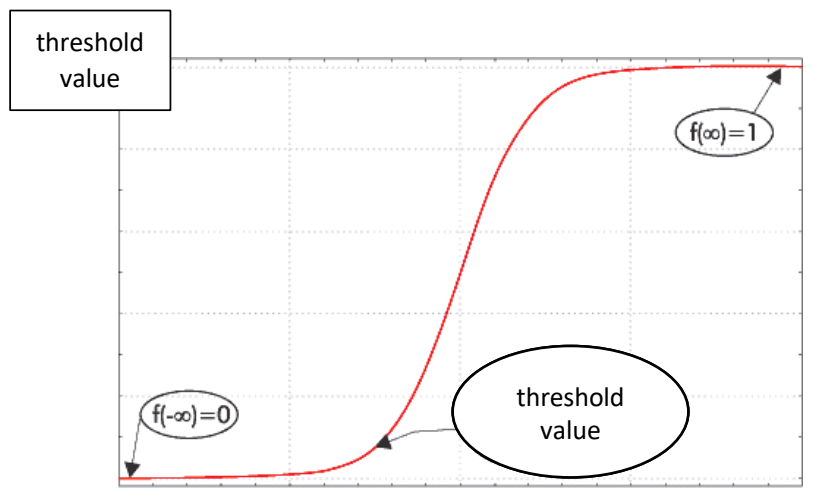

Fig. 1. Logistic function.

The logistic model owes its popularity mainly to two features:

1. The logistic function adopts values from 0 to 1 . The model may describe probability values which always lay between 0 and 1 . This probability determined the chances that e.g. a person gets to know the notion of eco-driving.

2. The shape of the function resembles an extended letter S. It shows that its changes are minimal if the variable values are lower than a certain threshold value. If they exceed the threshold, the function value starts to increase rapidly to 1 ; the probability remains on an exceptionally high level - almost 1 . The notion of a threshold value is often used in medical and epidemiological research.

While defining the "logistic model", $Y$ was assumed to be the dummy variable "Heard of eco-driving?" with the following values: 1 - yes ; 0 - no; and independent variables $X$.

Thus, the logistic regression model connecting the probability of one out of two possible results of the variable $Y$ with the explaining variables is determined with the following equation (2):

$$
P\left(Y=1 \mid x_{1}, x_{2}, \ldots, x_{k}\right)=\frac{e^{\left(a_{0}+\sum_{i=1}^{k} a_{i} x_{i}\right)}}{1+e^{\left(a_{0}+\sum_{i=1}^{k} a_{i} x_{i}\right)}}
$$


where: ai for $\mathrm{i}=0, \ldots, \mathrm{k}$ - regression ratio, $\mathrm{x} 1, \mathrm{x} 2, \ldots \mathrm{xk}$ - independent values took into consideration in research (from 1 to 7 ).

The left side of the equation is the conditional probability that variable $\mathrm{Y}$ will assumed a value equal 1 for the values of independent variables $\mathrm{x}_{1}, \mathrm{x}_{2}, \ldots \mathrm{x}_{\mathrm{k}}$.

In the case of the logistic model, similarly to any other regression model, the crucial role is played by regression coefficients at variables.

Both the possibility of their interpretation and the fact that they are statistically significant are important - what determined the relevance of the factor within the whole model, and as a consequence leads to identification of variables, the influence of which on progression is of real significance.

The above-mentioned example (Table 4.) includes a final form of the model, where only two variables significantly connected with the dependent variable are left. In the logistic model there is also this additional parameter defined as the odds ratio. This parameter is frequently employed in clinical and epidemiological studies.

A "chance" is the ratio of probability that the event occurs (e.g. the contact) to probability that the event does not occur. For the given example A, the above-mentioned definition may be expressed in the following formula (3):

$$
(\text { chance }) S(A)=\frac{P(A)}{P(\text { not } A)}=\frac{P(A)}{1-P(A)}
$$

for example: if $\mathrm{p}(\mathrm{A})=0.2$ then $\mathrm{S}(\mathrm{A})=0.2 /(1-0.2)=1 / 4$.

It means that the probability that case A will occur equals one fourth of the probability that this case will not occur. Thus, the chance that case A will not occur is 4 to 1 . Statistical significance $\chi^{2}$ is close to zero. Therefore, it is many times lower than 0.05 .

Hence, it can be concluded without any doubt that the analyzed model is appropriate, meaning that all independent variables that it includes exert some significant impact on ecodriving awareness.

\section{Factors contributing to eco-driving awareness}

\subsection{Average fuel price 2015-2017}

Two general populations of normal distribution $N\left(m_{1}, \sigma_{1}\right) N\left(m_{2}, \sigma_{2}\right)$ are provided, where standard deviations are unknown, and each sample size is at least 30 . The significance test is as follows (formula 4):

$$
u=\frac{\bar{x}_{1}-\bar{x}_{2}}{\sqrt{\frac{s_{1}^{2}}{n_{1}}+\frac{s_{2}^{2}}{n_{2}}}}
$$

where:

- $\bar{x}_{1}, \bar{x}_{2}$ are the average values from tests,

$-s_{1}^{2}, s_{2}^{2}$ are the standard deviations from tests,

$-n_{1}, n_{2}$ is the size of each sample.

The number of t-Student degrees of freedom distribution connected with this variance estimation is approximated by the Welch-Satterthwaite equation (formula 5): 


$$
v=\frac{\left(\frac{s_{1}^{2}}{n_{1}}+\frac{s_{2}^{2}}{n_{2}}\right)^{2}}{\frac{s_{1}^{4}}{n_{1}^{2} \cdot v_{1}}+\frac{s_{2}^{4}}{n_{2}^{2} \cdot v_{2}}}
$$

Table 1. Differences in average fuel consumption in the city between 2015 and 2017 (ON, PB95).

\begin{tabular}{|r|r|r|r|}
\hline & differences & $2015(\mathrm{x} 1)$ & \multicolumn{1}{c|}{2017 (x2) } \\
\hline PB95 & $\bar{x}=$ & PLN 3 599.23 & PLN 3 592.30 \\
\hline & $s=$ & PLN 245.31 & PLN 95.63 \\
\hline & $n=$ & 247 & 246 \\
\hline ON & $\bar{x}=$ & PLN 3 501.59 & PLN 3 493.59 \\
\hline & $s=$ & PLN 180.85 & PLN 119.49 \\
\hline & $n=$ & 243 & 246 \\
\hline & $\mathrm{u}(\mathrm{pb95}) ; p$ & 0.41 & 0.68 \\
\hline & $\mathrm{u}(\mathrm{ON}) ; p$ & 0.58 & 0.56 \\
\hline
\end{tabular}

\begin{tabular}{|c|c|}
\hline$\bullet$ & $\longrightarrow$ \\
\hline 3501.59 & 3493.59 \\
\hline PLN & PLN \\
\hline \multicolumn{2}{|c|}{$\longrightarrow$} \\
\hline 3599.23 & 3592.30 \\
\hline PLN & PLN \\
\hline 2015 & 2017 \\
\hline & \\
\hline
\end{tabular}

Fig. 2. Differences in average fuel consumption in the city between 2015 and 2017 (ON, PB95) graphical.

Average fuel consumption in the city, including both the diesel (ON) and unleaded petrol (PB95) in 2015 does not differ significantly from 2017 ( $\mathrm{p}=0.56$ and $\mathrm{p}=0.68$ ).

\subsection{Eco-driving awareness and factors that influence it}

The first issue which the answers were sought for was the relation between eco-driving awareness and a decrease in fuel consumption in the city (Table 2). 
Table 2. Logistic regression model results from factors significantly affecting awareness of ecodriving principles among respondents in 2017.

\begin{tabular}{|l|r|r|r|r|}
\hline & \multirow{2}{*}{$\begin{array}{c}\text { Constant } \\
\text { B0 }\end{array}$} & Gender & Age & \\
\cline { 3 - 5 } & & $\begin{array}{c}\text { Female }=1 \\
\text { Age* }\end{array}$ & & \\
Male $=2$ & & \\
\hline Coeff. & -3.75 & 0.31 & 0.75 & -0.82 \\
\hline COEFFICIENT & 0.76 & 0.12 & 0.35 & 0.34 \\
\hline $\mathrm{t}(989)$ & -4.96 & 2.57 & 2.12 & -2.44 \\
\hline buffing & 0.00 & 0.01 & 0.03 & 0.02 \\
\hline$-95 \% \mathrm{CL}$ & -5.23 & 0.07 & 0.06 & -1.48 \\
\hline$+95 \% \mathrm{CL}$ & -2.26 & 0.55 & 1.45 & -0.16 \\
\hline$\square^{2}$ Wald & 24.56 & 6.61 & 4.51 & 5.95 \\
\hline $\mathrm{p}$ & 0.00 & 0.01 & 0.03 & 0.01 \\
\hline OR $u$ & 0.02 & $\mathbf{1 . 3 7}$ & $\mathbf{2 . 1 3}$ & $\mathbf{0 . 4 4}$ \\
\hline$-95 \% \mathrm{CL}$ & 0.01 & 1.08 & 1.06 & 0.23 \\
\hline$+95 \% \mathrm{CL}$ & 0.10 & 1.74 & 4.27 & 0.85 \\
\hline OR $r$ & & 4.79 & 2.13 & 0.44 \\
\hline$-95 \% \mathrm{CL}$ & & 1.45 & 1.06 & 0.23 \\
\hline$+95 \% \mathrm{CL}$ & & 15.84 & 4.27 & 0.85 \\
\hline
\end{tabular}

*) Age: below $25=1 / 26$ to $30=2 / 31$ to $40=3 / 41$ to $50=4 / 51$ to $60=5 /$ above $60=6$

Model: Logistic regression (logit) N of 0's: 392 1's: 43

Dep. var: EcoAwareness Loss: Max likelihood (MS-err. scaled to 1)

Final loss: 132.76289513 Chi2( 3$)=15.093 \mathrm{p}=.00174$

The model shown in Table 2. suggests that the probability of eco-driving awareness decreases with each year of age. This means that the probability of the decrease in awareness grows with each subsequent age category by $38 \%$.

The research shows that women $(\mathrm{f}=2$; increase) are less aware of eco-driving - by about $112 \%$ - than men. While the respondents who consume less fuel are more aware by about $127 \%$.

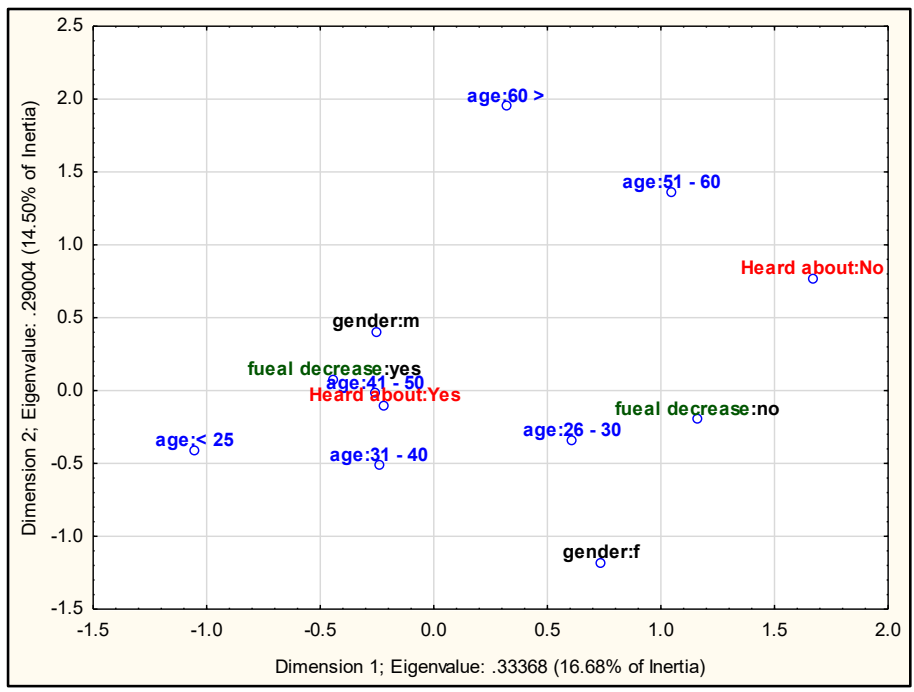

Fig. 3. Factors contributing to reduced fuel consumption in 2015 (age, gender). 
The confidence limits for the parameters (-/+95\% CL of evaluations) are not broad what proves high stability of the obtained results and suggests precise conclusions when interpreting the variables.

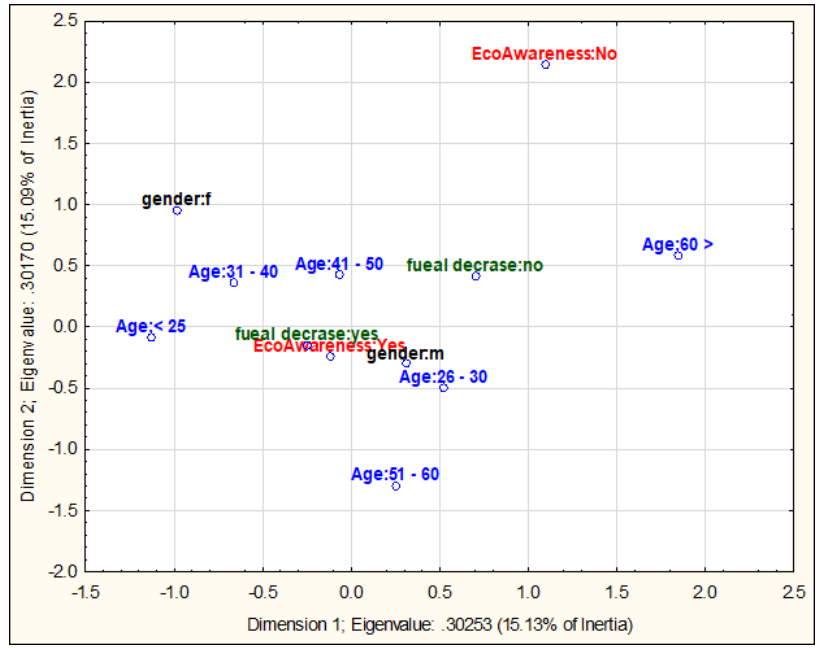

Fig. 4. Factors contributing to reduced fuel consumption in 2017 (age, gender).

Fig. 3. and Fig. 4. suggest that men were more aware of eco-driving in 2015, but it was not significant - and it became significant in 2017. At the same time, the awareness - first of all in the case of men - improved, while in the case of women it remained on the same level.

\subsection{Eco-driving awareness and technical aspects of its use}

Table 3. Logistic regression model results from factors significantly affecting awareness of ecodriving principles among respondents in 2015.

\begin{tabular}{|l|c|c|c|c|}
\hline & $\begin{array}{c}\text { Constant } \\
\text { B0 }\end{array}$ & $\begin{array}{c}\text { ep2_2 reduction of } \\
\text { pollution }\end{array}$ & $\begin{array}{l}\text { ep2_3 saving of } \\
\text { natural resources }\end{array}$ & $\begin{array}{c}\text { ep33 engine } \\
\text { braking }\end{array}$ \\
\hline Coeff. & -2.13 & 0.48 & -0.81 & -0.56 \\
\hline COEFFICIENT & 0.57 & 0.23 & 0.25 & 0.29 \\
\hline $\mathrm{t}(989)$ & -3.71 & 2.10 & -3.27 & -1.93 \\
\hline Buffing & 0.00 & 0.04 & 0.00 & 0.05 \\
\hline$-95 \%$ CL & -3.26 & 0.03 & -1.29 & -1.13 \\
\hline$+95 \%$ CL & -1.00 & 0.94 & -0.32 & 0.01 \\
\hline$\square^{2}$ Wald & 13.74 & 4.40 & 10.68 & 3.73 \\
\hline Buffing & 0.00 & 0.04 & 0.00 & 0.05 \\
\hline ORu & 0.12 & $\mathbf{1 . 6 2}$ & $\mathbf{0 . 4 5}$ & 0.57 \\
\hline$-95 \% \mathrm{CL}$ & 0.04 & 1.03 & 0.28 & 0.32 \\
\hline$+95 \% \mathrm{CL}$ & 0.37 & 2.55 & 0.73 & 1.01 \\
\hline OR $r$ & & 1.62 & 0.45 & 0.57 \\
\hline$-95 \% \mathrm{CL}$ & & 1.03 & 0.28 & 0.32 \\
\hline$+95 \% \mathrm{CL}$ & & 2.55 & 0.73 & 1.01 \\
\hline
\end{tabular}

Model: Logistic regression (logit) N of 0's: 332 1's: 126 (Moto Scan 2015 - Ekojazda v2 in EcoDriving 20152017 v036.stw)

Dep. var: Mspadek Loss: Max likelihood (MS-err. scaled to 1)

Final loss: 250.54510417 Chi2 ( 5) $=37.769 \mathrm{p}=.00000 \mathrm{~N}=458$ 
Table 4. Logistic regression model results from factors significantly affecting awareness of ecodriving principles among respondents in 2017.

\begin{tabular}{|l|c|c|c|c|}
\hline & $\begin{array}{c}\text { Constant } \\
\text { B0 }\end{array}$ & $\begin{array}{c}\text { ep2_2 reduction of } \\
\text { pollution }\end{array}$ & $\begin{array}{l}\text { ep2_3 saving of } \\
\text { natural resources }\end{array}$ & $\begin{array}{c}\text { ep33 engine } \\
\text { braking }\end{array}$ \\
\hline Coeff. & 0.37 & -0.58 & 0.84 & 0.74 \\
\hline COEFFICIENT & 0.31 & 0.23 & 0.25 & 0.31 \\
\hline $\mathrm{t}(989)$ & 1.22 & -2.54 & 3.33 & 2.36 \\
\hline buffing & 0.22 & 0.01 & 0.00 & 0.02 \\
\hline$-95 \%$ CL & -0.23 & -1.03 & 0.34 & 0.12 \\
\hline$+95 \%$ CL & 0.97 & -0.13 & 1.34 & 1.35 \\
\hline$\square^{2}$ Wald & 1.49 & 6.48 & 11.08 & 5.58 \\
\hline buffing & 0.22 & 0.01 & 0.00 & 0.02 \\
\hline OR $u$ & 1.45 & $\mathbf{0 . 5 6}$ & $\mathbf{2 . 3 2}$ & $\mathbf{2 . 0 9}$ \\
\hline$-95 \% \mathrm{CL}$ & 0.80 & 0.36 & 1.41 & 1.13 \\
\hline$+95 \% \mathrm{CL}$ & 2.65 & 0.88 & 3.80 & 3.85 \\
\hline OR $r$ & & 0.56 & 2.32 & 2.09 \\
\hline$-95 \% \mathrm{CL}$ & & 0.36 & 1.41 & 1.13 \\
\hline$+95 \% \mathrm{CL}$ & & 0.88 & 3.80 & 3.85 \\
\hline
\end{tabular}

Model: Logistic regression (logit) N of 0's: 115 1's: 320 (Moto Scan 2017 - Ekojazda in EcoDriving 20152017 v036.stw)

Dep. var: fuel decrease Loss: Max likelihood (MS-err. scaled to 1)

Final loss: 239.95379188 Chi2 ( 3$)=22.584 p=.00005$

$\mathrm{N}=435$

As suggested by Table 3. and Table 4., gender played an important role in 2015, but within the course of time, the awareness allowed to make the decrease in fuel consumption independent of such factors, and to focus only on technical aspects in 2017 such as: reduction of pollution, saving of natural resources, engine braking.

\section{Conclusions}

Studies described in the literature on pollutant emissions and driving styles prove that the driving style exerts certain influence on emission of gaseous substances in exhaust fume and fuel consumption. There is a need to note that the road emission value of these compounds increased significantly because of aggressive driving and decreased noticeably thanks to ecological and economic driving style, namely the eco-driving. Therefore, the aggressive driving style impacts not only the size of fuel consumption but also the environment, people and driving safety. However, a change in the behaviors of drivers requires adequate national policy regarding development of the country's ecological safety, an increase in ecological awareness and different attitudes of the drivers themselves.

\section{References}

1. D. Kiełczewski, B. Dobrzańska, Ekologiczne problemy zrównoważonego rozwoju (Wyd. WSE, Białystok, 2009)

2. P.O. Czechowski, A. Oniszczuk-Jastrząbek, T. Czuba, Eco-driving: behavioural pattern change in Polish passenger vehicle drivers [in:] X Konferencja Naukowa Ochrony Powietrza w Teorii i Praktyce. E3S Web of Conferences, 28, 1-8 (2018) 
3. O. Dębicka, A. Oniszczuk-Jastrząbek, T. Gutowski, J. Winiarski, Przedsiębiorstwo w otoczeniu globalnym (UG, Gdańsk, 2009)

4. ̌. Hittmár, The Selected Problems for the Development Support of Management Knowledge Base (University of Zilina, Zilina, 2014)

5. B. Kryk, Wycena strat ekologicznych wynikajacych $z$ działalności energetyki w regionie szczecińskim (Wydział Ekonomiczny US, Szczecin, 1993)

6. D. Kopycińska, Zeszyty naukowe Uniwersytetu Szczecińskiego, nr 367, Prace Katedry Mikroekonomii 8 (2003)

7. Impact Assessment. Accompanying document to the White Paper. SEC 358 final. European Commision (2011)

8. B. Pawłowska, Doświadczenia europejskie w zakresie metodologii szacowania kosztów zewnętrznych wypadków drogowych. Materiały wewnętrzne: prezentacja. Katedra Badań Porównawczych Systemów Transportowych. Międzynarodowe Seminarium GAMBIT (2008)

9. B. Pawłowska, Zewnętrzne koszty transportu. Problem ekonomicznej wyceny (Wyd. WUG, Gdańsk, 2000)

10. T. Jemczura, H. Kretek, Zrównoważony Rozwój - Debiut Naukowy 2011, (Racibórz 2012)

11. K. Boriboonsomsin, A. Vu, M. Barth, Eco-Driving: Pilot Evaluation of DrivingBehavior Changes among U.S. Drivers (University of California Transportation Center, 2010)

12. R. Andoa, Y. Nishihori, Procedia Social and Behavioral Sciences 20, 577-587 (2011)

13. C. Andrieu, G. Saint Pierre, Comparing effects of eco-driving training and simple advices on driving behawior, Procedia - Social and Behavioral Sciences 54, 211 - 220 (2012)

14. A. Schroten, Behavioural Climate Change Mitigation Options, Domain Report Transport (CE Delft, 2012)

15. D.G. Kleinbaum, L.L. Kupper, A. Nizam, K.E. Muller, Applied Regression Analysis and Other Multivariable Methods (Duxbury Press, 2008)

16. A.E. Wahlberg, International Journal of Industrial Ergonomics 37, 333-343 (2007)

17. M. Zarkadoula, G. Zoidis, E. Tritopoulou, Transportation Research Part D 12, 449-451 (2007)

18. J. Merkisz, M. Andrzejewski, J. Pielecha, Combustion Engines. 155(4), 66-74 (2013)

19. E. Tokarczyk, Transport Samochodowy 1 (2012)

20. A. Stanisz, Modele regresji logistycznej (2016)

21. A. Stanisz, Przystepny kurs statystyki z zastosowaniem Statistica PL na przykładach z medycyny, T. 1, 2, 3, (StatSoft, 2009-2012)

22. W. Rogula-Kozłowska, G. Majewski, P.O. Czechowski,, Environ Monit Assess, 187$240(2015)$

23. M. Pokorski, Respiratory Regulation - Clinical Advances. Advances in Experimental Medicine and Biology, 755 (2013) 